RECENT EXCAVATIONS ON A PALEOLITHIC DITE IN JERSEY.

$\mathrm{D}$ URING the past summer excavations on the Palæolithic site known as La Cotte at St. Brelade, in Jersey, have been pushed on vigorously. When the work for the year came to an end in I9I4 a trench had been driven across the cave from the western to the eastern side-wall, a distance of about $40 \mathrm{ft}$. This trench was about $8 \mathrm{ft}$. from the entrance. The excavations undertaken this year had three objects in view: first, to extend the examination of the Palæolithic floor along the western side-wall, of which $25 \mathrm{ft}$. in an inward direction had been uncovered in I9II, and if possible reach the hitherto undetermined back-wall; secondly, to clear the entrance of the cave along its whole breadth by removing the barrier of talus, about $25 \mathrm{ft}$. high, on the outer side of the trench; and lastly, on the inner side of the clearing thus made, to push along the eastern side-wall.

The work of excavation is being carried on by the Sociéte Jersiaise, with the assistance of a committee of the British Association of which Dr. R. R. Marett is chairman. So much of the season's work as had been completed by the end of July was embodied in a report presented to the British Association at the Manchester meeting; but at that time not one-half of the season's work was over. Before describing the later results, it will be convenient to give a brief summary of what had already been done for those who may not have seen the report. The opening up of the Palæolithic floor along the western wall was carried forward a further $5 \mathrm{ft}$., worked flints being found sparsely at about 2 to $4 \mathrm{ft}$. above bench-mark. The cave was cleared across its entire front. The central part proved sterile, but a richly implementiferous bed, reaching from floor level to a height of $\mathrm{I} 2 \mathrm{ft}$., was found under a ledge projecting some $\mathrm{I}_{2} \mathrm{ft}$. along the eastern side-wall. The finds, in addition to worked flints, included a large number of cores and hammer stones. There was also a great deal of bone in fair condition, one piece being apparently the knuckle-bone of a mammoth. A specially fine set of "hemi-Solutrian" implements occurred along the top of this bed. The working under the eastern wall was pushed forward for a distance of $27 \mathrm{ft}$., and revealed a quantity of burnt bone, indicating a former hearth. Flint was plentiful but of coarse pattern.

This was the extent of the work which had been carried out at the end of July. But by that time the roof of the cave, which consisted of masses of detached blocks, weighing anything up to ten or twelve tons, held in place by clay, had become unsafe. By dynamite and other means, however, all loose blocks, amounting to many tons, were removed, and the cave made reasonably safe after a fortnight's hard work. Excavations were then continued along the western side-wall for a further distance of $6 \mathrm{ft}$., when a projecting shelf of live rock was reached. On investigation it appeared that this was not the end of the cave. The shelf was undercut by a cavity penetrating inward at an angle of $45^{\circ}$. Here among other implements was found one of the most perfect of Mousterian "points" hitherto obtained on the site.

The working across the front of the cave proved rich in implements, but only up to the line corresponding to the line of the roof; beyond that it yielded nothing. The clearing of the débris on the inner side of the trench was begun and carried to a depth of about $30 \mathrm{ft}$. from the entrance right across the breadth of the cave. The breccia in the centre proved as rich in implements as the side-wall workings. The bone was in good condition, and included a magnificent tooth of a prehistoric elephant (? Antiquus) virtually intact. The implements for the most part were of a coarse type, but finer types occurred among them.

So much for the work of the month of August. It was proposed to carry on excavations throughout September in the hope of reaching the back wall of the cave. It was realised, however, that the work of clearing the undercutting on the western side was a danger. It had cleared away the support of a column of loose rock-rubbish, some 30 or $40 \mathrm{ft}$. thick, which had descended on the cave through a more or less vertical funnel. After two days' work, which proved remarkably rich in finds, the roof of the cave collapsed. Careful watch had been kept and no one was hurt, though warning was short-only a matter of minutes. About rooo sq. ft. of floor had been opened up, but these workings are now completely buried under débris. As further falls are expected, work has been closed for the year.

Inspection of the chimney, the sides of which are now revealed, shows that another $20 \mathrm{ft}$. would have reached the cliff wall. It is probable, therefore, that the line of least resistance when work begins again will be to attack the cave from the back. In the meantime, the members of the Société Jersiaise and of the committee in charge of the exploration are busily engaged in sorting and classifying the finds. That this is a work of some masnitude will be gathered from the fact that in the past season some 3000 shaped implements, besides much workshop refuse and bone, have been taken from the site. Both in the number and the character of the finds it has proved one of the richest Palæolithic sites in Europe.

E. N. Fallaize.

\section{THE LIGHTING OF FACTORIES AND WORKSHOPS. 1}

$A \mathrm{~T}$ the present time, when so many factories are $A$ working at high pressure on Government contracts, the condition of workers well deserves scientific study. This point is emphasised by the recent appointment by the Minister of Munitions of War, with the concurrence of the Home Secretary, of a committee "to inquire and advise on questions of industrial fatigue, hours of labour, and other matters affecting the health and physical efficiency of workers in munition factories and workshops."

One matter of considerable importance in the factory-the matter of lighting-has just been dealt with in the First Report of the Departmental Committee appointed by the Home Secretary in 1913. The inquiry demanded special methods of investigation, and the committee has carried out a considerable amount of work. Evidence has been received from fifty witnesses, including inspectors of factories and representatives of various trade associations and scientific and technical societies. Eighty-five works in the chief industrial centres have been visited, and about 4000 measurements of illumination carried out. A series of experiments bearing on the standards of illumination required for various purposes was carried out at the National Physical Laboratory.

Inquiries were also made, through the Foreign Office, into the legislation relating to lighting in all the chief European countries and the United States, and the results are published in an appendix. In the United Kingdom no general provisions in regard to lighting (analogous to those regarding heating and ventilation) occur in the Factory Acts, although adequate lighting is required, in general terms, in underground bakehouses and in certain dangerous

1 First Report of the Departmental Committee on Lighting in Factories and Workshops. Vol. i., Report and Appendices (Cd. 8000); Vol. ii., Minutes of Evidence, etc. (Cd. 800r). (London: H.M.S.O. and Wyman and Sons.) Vol. i., Ird.; Vol. ii., rs. $7 d$.

NO. 2400, VOL. 96$]$ 
trades. On the other hand, the codes of all the chief European countries, the United States, and India contain provisions requiring adequate lighting in factories.

The results of bad lighting have been studied in detail. A statistical inquiry into the number of accidents in various industries in each month of the year points to the conclusion that inadequate lighting is a contributory cause of accidents ; it is significant that in mines the number of fatal accidents in surface work is greater in the winter when there is less davlight available, and the "accident rate" in most industries studied is considerably greater by artificial than by natural illumination. The evidence of witnesses and the statements of the Accident Offices Association, which embraces most of the insurance companies interested in the Workman's Compensation Aci, supports this view. Specific instances are quoted of the effect of improved lighting in increasing the output and quality of work, and there is a general impression that unsatisfactory lighting is, in various ways, prejudicial to health.

The committee recommends that:-

(I) There should be a statutory provision :-

(a) Requiring adequate and suitable lighting in general terms in every part of a factory and workshop, and

(b) Giving power to the Secretary of State to make Orders defining adequate and suitable illumination for factories and workshops or for any parts thereof or for any processes carried on therein.

It is pointed out that "adequate lighting" should comply with the following requirements :-

(a) Adequacy.

(b) A reassnable degree of constancy and uniformity of illumination over the necessary area of work.

(c) The placing or shading of lamps so that the light from them does not fall directly in the eyes of an operator when engaged on his work, or when looking horizontally across the workroom.

(d) The placing of lights so as to avoid the casting of extraneous shadows on the work.

Certain recommendations are also made regarding the amount of illumination necessary in the working areas of factories, in foundries, dangerous parts of ways and open spaces, etc., and there is a special recommendation providing for exemption in special cases. These values, which range from $0.05-0.4 \mathrm{ft}$.candle, are prescribed in the interests of safety and convenience, and without prejudice to the special illumination required for the carrying on of work. At present the committee is not prepared to recommend standards of illumination for various classes of work which require further investigation.

In the appendices, the measurements of illumination in various classes of factories are tabulated in such a way as to show the average values existing, and it is shown that the above values, which are suggested as a practical legal minimum, impose no hardship. Many manufacturers would prefer to provide substantially higher values, and these recommendations would be mainly instrumental in improving the illumination in out-of-date factories which have lagged behind the general advance. Besides carrying out tests of the artificial lighting in factories in terms of foot-candles, the committee has also accumulated a considerable amount of information regarding the natural illumination. This is expressed in terms of the "daylight factor" (i.e. the relation between the illumination inside a workroom and the total unrestricted illumination out of doors). The experiments at the National Physical Laboratory illustrate the connection existing between the amount of illumination required and the character of the material illuminated, which may be expressed thus :-.

No. 2400 , VOL. 96]
Coefficient of reflection of material $\times$ illumination necessary $=$ constant.

Other experiments bear on the relative merits of direct and indirect lighting for certain classes of work. The visibility of detail consisting of fabrics, embossed papers, engraved metal, etc., demands unidirectional illumination, and the ability to distinguish such detail is, for the same illumination, greater by direct than by indirect light.

An enterprising step in connection with this report is the issue of a short memorandum summarising its aims and conclusions, and pointing out the special interest attaching to the report at the present time, when so many factories are working overtime and preparations are being made for the period of the year when artificial lighting is mainly required.

\section{THE TURQUOISE. ${ }^{1}$}

IRING several years, whilst a curator in the United States National Museum, Dr. Pogue collected all the available information respecting this familiar gem-mineral, visiting for this purpose the principal museums and libraries of America and Europe. The result is an elaborate compilation with numerous footnotes giving references to the scattered literature of the subject. Being an exhaustive treatise on turquoise, although containing practically no original matter, it would have been more accessible and convenient for reference if it had been issued as a separate octavo volume, rather than being buried in the large quarto volumes of an academy publication.

The various aspects under which the subject is treated are indicated in the title. The section on geology contains a detailed account of the occurrence of the mineral at all its known localities, particularly those in Persia, the Sinai Peninsula, and the southwestern portion of the United States. The States of New Mexico, Arizona, California, Nevada, and Colorado, where many ancient workings are known, have recently become important sources of the mineral, producing stones rivalling the Persian in quality. A useful table is given stating the enclosing rocks (mainly igneous rocks, and especially trachyte), the associated minerals (usually limonite, kaolin, and sericite), etc.y for the more important turquoise occurrences. The mode or modes of origin of the mineral are discussed, and the general conclusion drawn that it has been formed by the percolation of surface waters through aluminous rocks containing apatite and disseminated copper minerals. An attempt is made to disentangle the confusion associated with the name "chalchihuitl" of the American aborigines. Although the early Spaniards confused several green stones under this name, it would appear that the Indians of the south-western States referred to turquoise, whilst in Mexico the material so-called was mainly jade. A detailed bibliography and a good index complete the work. The plates are, for the most part, devoted to representations of ancient orna ments set with turquoises.

L. J. S.

\section{PURPOSEFUL FORAMINIFERS.}

$\mathrm{M}$

R. EDWARD HERON-ALLEN is to be congratulated on the interesting results which are rewarding his assiduous study of the Foraminifera. His latest contribution (Phil. Trans., June, I9I5) deals with the processes of reproduction and of shell-making. In addition to the production of zoospores observed

1 "The Turquoise. A Study of its History, M ineralogy, Geology. Ethno. logy, Archaology, Mythology, Folklore, and Technology." By J. E. Pogue. Memoirs of the National Academy of Sciences, Washington, D.C., Igr5, vol. xii., part ii., 3rd Memoir, pp. 162, 22 plates.
rel 